$\begin{array}{ccc}\text { Tanggal diterima } & \text { Tanggal direvisi } & \text { Tanggal Terbit } \\ \text { 28 Januari 2019 } & \text { 27 Februari 2019 } & \text { 25 Maret 2019 }\end{array}$

\title{
Dikotomi Pendidikan Agama Islam Dan Pendidikan Umum di Indonesia
}

\author{
Badrut Tamami \\ Dosen Program Studi Pendidikan Agama Islam Fakultas Agama Islam \\ Universitas Muhammadiyah Jember \\ Email : badruttamami@unmuhjember.ac.id
}

\begin{abstract}
Dichotomy in education merely aims at creating a system for compartmentalization or restrictions on practitioners in the world of education, differentiating between religious with general education, state-based with private-based schools, centralistic education and independent self-reliance in a policy, as well as in terms of facilities and resources, employment, and buman resources. As a form of embodiment in fostering education for moral values and moral character, education on Islamic religion at school is crucial to form good personality of students who have a fundamental principle of carrying out the commands of Islamic law and avoiding being probibited, and implementing the value of worship in daily activities vertical in nature with the creator and horizontal fellow bumans with courtesy and ethics. The method in this paper is the result of a critical analysis of some phenomena in the world of education in Indonesia and took several references, articles, journals by concluding that there is a dichotomy between the majority of Islamic religious education and public education as the majority of people as steak holders. between these differences without them know about such issues. The author formulates with a title: Dichotomy in Islamic and General Education in Indonesia.
\end{abstract}

Keywords: Dichotomy, Islamic Education, General Education

Abstrak

Dikotomi dalam dunia pendidikan hanyalah membentuk sebuah sistem pengkotak-kotakan atau pembatasan pada praktisi yang ada di dunia pendidikan, perbedaan pendidikan Agama dengan pendidikan umum, sekolah berbasis Negeri dengan sekolah berbasis swasta, pendidikan sentralistik maupun berdikari mandiri dalam sebuah kebijakan,serta dari segi sarana dan prasarana, ketenagakerjaan, dan sumber daya Manusia. Sebagai bentuk perwujudan dalam pembinaan nilai-nilai pendidikan karakter yang bermoral dan berakhlakul karimah, Pendidikan agama islam di sekolah tentu sangatlah penting sebagai bentuk kepribadian anak didik yang mempunyai prinsip mendasar melaksanakan perintah syariat Islam dan menjauhi suatu yang dilarang, dan mengimplementasikan nilai ibadah dalam aktivitas keseharian bersifat vertical dengan sang pencipta maupun horizontal sesama manusia dengan santun dan beretika.Metode dalam Tulisan ini adalah hasil pendekatan analisis kritis beberapa fenomenalogis pada dunia pendidikan di Indonesia dan diambilkan beberapa rujukan referensi penulis buku, Artikel, jurnal ilmiah dengan menyimpulkan terjadi sebuah dikotomi perbedaan pendidikan agama islam dan pendidikan umum yang mayoritas masyarakat selaku steak holder mulai memilih dan memilah antara perbedaan tersebut tanpa mereka sadari. penulis merumuskan dengan sebuah judul : Dikotomi Pendidikan Agama Islam Dan Pendidikan Umum di Indonesia.

Kata Kunci : Dikotomi, Pendidikan Agama Islam, Pendidikan Umum

\section{PENDAHULUAN}

Fenomena kenakalan remaja dari tahun ke tahun mengalami grafik peningkatan yang cukup drastis, serta tindak korupsi yang sudah mengakar 
kuat di negeri ini. Kondisi ini tidak mungkin terus dibiarkan secara berlarut-larut, tanpa adanya peningkatan kualitas pendidikan agama untuk meminimalisir terjadinya hal tersebut. Pendidikan Agama di Indonesia memang tidak bisa di pisahkan lagi dari lembaga sekolah yang ada,oleh karena itu fakta yang ada di Negara Indonesia masih mengalami degradasi akhlak dan moral dari sisi karakteristik pola pikir dibandingkan dengan Negara lain yang baru saja mengalami kemerdekaan (Kurniyati, 2018).

Pembinaan karakteristik kepribadian anak sangat penting untuk pertumbuhan dan pembentukan sisi moral dan aspek jiwa social anak didik,melatih dan memberikan pembiasaan untuk melaksanakan perintah agama dan meninggalkan laranganya serta memberikan contoh dalam pelaksanaan praktek ibadah, bergaul dengan sesama secara sopan dan santun, menjunjung tinggi sikap toleransi dan selalu berfikir secara dewasa dalam menghadapi suatu permasalahan dan mencari solusi yang tepat tanpa adanya pihak yang dirugikan.

Salah satu cara untuk mengahadapi masa depan yang cerah adalah dengan mengutamakan aspek pendidikan. melalui proses pembelajaran itulah anak dapat menentukan kehidupan bersosialisasi, beradaptasi di dalam kultur budaya primer yaitu dalam lingkungan keluarga. unsur pewarisan budaya dalam hal ini merupakan proses pembelajaran yang dilakukan pertama kali. Dalam referensi ilmu sosial dijelaskan bahwa kebudayaan diartikan sebagai suatu keseluruhan sistem social, ide, dan hasil cipta karya manusia atas dasar kehidupan masyarakat yang dimilikinya melalui proses pembelajaran.
Pada zaman kolonial belanda hinggga saat ini terdapat faktor tendensi mengarah pada pembentukan kultur pola pikir budaya yang mengakar kuat pada masyarakat, yaitu klasifikasi pembagian istilah antara lembaga negeri dan lembaga swasta, agama dan umum, desentralisasi dengan sentralistik, menejemen berbasis sekolahan dan menejemen berbasis pusat, kurikulum berbasis kompetensi dan kurikulum berbasis pengetahuan, yang semuanya merupakan bagian dari peristiwa sejarah atas penjajahan belanda kepada bangsa Indonesia.

Permasalahan pada bidang pendidikan di beberapa peristiwa yang ada di Indonesia dapatlah dianalisis sebagai berikut, dalam Sistem kelola bidang pendidikan di Indonesia terdapat dua kementerian yang menangani sebuah lembaga pendidikan, yaitu kementerian Pendidikan Nasional dan kementerian Agama.yang mempunyai fungsi berbeda terkait dengan kurikulum, kementerian Pendidikan Nasional dengan menggunakan Kurikulum secara Umum sedangkan kementerian Agama menggunakan Kurikulum yang berbasiskan Pendidikan Agama dan bidang keagamaan. Sehingga dalam tawaran konsep dan paradigma bidang pendidikan di Indonesia menyebabkan pengaruh terjadinya dikotomi pendidikan dan dualisme pendidikan.

Pendidikan agama Islam merupakan tonggak perwujudan nilai moral dan karakteristik yang ada di sekolah umum maupun di madrasah, akan tetapi keberadaan mata pelajaran pendidikan Agama Islam masih dipandang sebelah mata dan diremehkan oleh banyak pihak termasuk salah satunya dewan guru yang mengampu mata pelajaran bersifat umum, eksakta, teknologi. Serta 
kurangnya perhatian yang serius dari pemerintah dalam memberikan pelatihan, ketrampilan dan mengikuti seminar atau workshop, menyebabkan guru pendidikan Agama islam kurang begitu menarik dalam menyampaikan materi keagamaan sehingga terkesan monoton dan menjenuhkan.

\section{PEMBAHASAN}

\section{Definisi Dikotomi}

Dalam bahasa Inggris Dikotomi adalah pembagian dua kelompok yang saling bertentangan, pembelahan dua, Ada yang mengartikan dikotomi sebagai pembagian dua bagian, bercabang dua bagian.Secara terminologis, dikotomi dapat diartikan sebagai sebuah pembatas antara bidang ilmu dan bidang agama yang terus menerus mengalami perubahan dan pengkotakan sistem, contohnya yaitu dikotomi ahli agama atau ulama dengan para intelektual, dikotomi pendidikan Islam dan bahkan dikotomi dalam diri muslim itu sendiri (split personality). Bagi al- Faruqi, dikotomi adalah dualisme religius dan cultural.

Dikotomi ilmu dan Agama dalam sejarah peradaban Islam cukup berpengaruh dalam pembentukan pola berpikir masyarakat yang dilanjutkan dengan semakin berkembangnya lembaga-lembaga pendidikan Islam di Nusantara, merupakan sebuah masalah kontemporer yang keberadaannya tidak terlepas dari sebuah proses sejarah penjajahan yang panjang sehingga bisa muncul sekarang ini. Proses sejarah tersebut diawali perkembangan pertemuan kultur budaya Islam-Arab dengan budaya lainnya, yang kemudian diakhiri dengan pertentangan oleh kultur keduanya.

Terkait penjelasan makna dikotomi tersebut, maka dualisme sistem pendidikan di Indonesia antara pendidikan umum dan pendidikan agama Islam yang dapat memisahkan kesadaran keagamaan dan ilmu pengetahuan bagi stekholder merupakan akibat dari adanya dikotomi dalam dunia pendidikan Islam itu sendiri. tidak hanya pada pemilahan tetapi masuk pada wilayah pemisahan, dalam pelaksanaannya menjadi pemisah antara mata pelajaran agama dengan mata pelajaran umum, madrasah dengan sekolah umum, pengelolaannya mempunyai kebijakan sendiri. dikotomik pada Sistem pendidikan islam bisa menyebabkan terpecahnya peradaban Islam dan akan menafikan peradaban Islam yang sempurna.

\section{Definisi Dualisme}

Istilah dualisme dalam bahasa latin merupakan gabungan antara dua kata yaitu duals atau duo dan ismus. duals mempunyai arti kata dua. Sedangkan ismus mempunyai fungsi untuk membentuk satu nama kata kerja. Dualisme merupakan dua prinsip yang tidak bisa disatukan atau saling bertentangan. dualisme Secara terminologi diartikan sebagai paham yang berbeda, dua prinsip yang saling bertentangan. Oleh karena itu dualisme merupakan keadaan dua substansi, suatu sistem atau teori yang berdasarkan dua prinsip yang berbeda.

Pada hakikatnya dualisme merupakan sebuah doktrin metafisika dan filsafat yang terbentuk oleh pemikiran para filosof Barat dalam melihat entitas jiwa dan raga manusia. Pada mulanya konsep dualisme dalam pandangan hidup tentang alam (world view) yang membentuk peradaban budaya Barat. ide tentang dualisme sebenarnya dapat dipelajari semenjak zaman Plato dan Aristoteles yang mempunyai eksistensi jiwa 
yang terkait dengan kecerdasan dan kebijakan.

Pemahaman Dualisme adalah realita kenyataan dari dua sudut pandang, yaitu materi dan akal adalah dua substansi yang terpisah secara ontologism, Aristoteles dan Plato mengemukakan bahwa kecerdasan seseorang adalah bagian dari jiwa dan fikiran manusia dan tidak bisa dijelaskan dengan fisik atau nyata saja. dalam kaitannya antara jiwa dengan raga, mental merupakan sebuah entitas non-fisik sedangkan raga merupakan fisik. sedangkan secara ideologis adanya dualisme pendidikan, yaitu sekolah umum yang memperoleh sokongan pemerintah dan menjadi tanggung jawab Kementerian Pendidikan Nasional dan madrasah, pondok pesantren, sekolah yang kurang mendapat perhatian dan menjadi tanggung jawab Kementerian Agama.

\section{Perspektif Islam tentang dualisme dan dikotomi pendidikan}

Dalam Al-Quran dan Al Hadits dapat di analisa dan dikaji tentang terjadinya dualisme dan dikotomi dalam pendidikan Ilmu sebagai dasar pijakan, sebagaimana dijelaskan oleh Prof. Quraish Shihab, kata ilmu dengan berbagai bentuknya terulang 854 kali dalam al-Quran dan 750 ayat alQuran yang berbicara tentang alam materi dan fenomenanya. Selain itu banyak ayat al-Quran yang memerintahkan untuk berfikir tentang alam semesta, melakukan perjalanan dengan titik tolak dan tujuan akhir karena Allah, seperti dalam Surat Al-'Alaq sebagai surat yang pertama kali diturunkan diawali dengan kalimat Iqra dan diakhiri dengan kalimat "wasjud waqtarib" ini merupakan indikator bahwa ilmu dalam Islam tidak dikenal Ilmu hanya untuk ilmu dan tidak dibenarkan dalam Islam. Sementara sekarang ini berkembang ilmu itu bebas nilai.

Para ulama terdahulu, tidak membedakan ilmu agama dengan ilmu umum, keduanya sama penting, contohnya menurut Muhammad Abduh, , adanya skala prioritas utama dimana ilmu agama diberikan dan diajarkan pada masa kecil karena merupakan kebutuhan dasar sebagai orang beragama dan landasan dasar hakikat agamanya, mempunya karakteristik identitas keagamaan yang kuat, serta pondasi moral visi dakwah yang jelas. Ulama terdahulu begitu menguasai dan menghargai keutamaan berbagai disiplin ilmu dilihat dari otoritas keilmuan yang mereka miliki dan kuasai.

Beberapa ulama zaman terdahulu sekaligus ilmuwan seperti halnya Al-Kindi merupakan seorang ilmuwan sekaligus filosof, Al-Farabi. Ibnu Sina, yang ahli dalam bidang kedokteran, music, filsafat, dan psikologi, beliau juga seorang ulama tersohor. al-Ghazali, yang terkenal dengan kehidupan dan ajaran sufinya, Al-Khawarizimi ulama yang juga ahli matematika, beliau kesemuanya telah menguasai berbagai bidang ilmu, mulai dari ilmu tasawuf ,figh, filsafat,dan ilmu kalam, Begitu pula Ibnu Rusyd, seorang ulama fiqih yang telah membuat karya magnum opus-nya yaitu Bidayat Al-Mujtahid, mengsinergikan ilmu fiqh dengan filsafat. Ibnu Khaldun terkenal sebagai ulama sosiolog modern dalam magnum opus-nya Al-Mukaddimah, saat ini banyak ahli yang mempelajari baik dari dari kalangan ummat Islam maupun para kapitalisme.

Oleh karena itu ada kalanya bidang disiplin ilmu masih memerlukan ilmu penunjang dari bidang ilmu yang lainnya, kesemuanya saling melengkapi sehingga para ulama terdahulu bisa 
menghasilkan karya yang berkualitas dan berbobot hingga bertahan dalam waktu yang relative lama, karena mereka mempunyai berbagai bidang keilmuan multi-disipliner. Menurut Arifin, AlQuran sebagai sumber rujukan hukum dan petunjuk manusia, dua pertiga ayat Al-Quran berisi motivasi proses pembelajaran dan pengalaman bagi manusia. Allah Yang Maha Kuasa secara langsung menjadikan manusiamempunya sifat yang baik atau sifat jahat, kepandaian atau bodoh, kebahagiaan atau kesedihan, kesehatan atau sakit, semua tidak lain pada hakekatnya sebuah hukum kausalitas atau hukum sebab-akibat.

Keselarasan kehidupan di dunia dan akhirat menunjukkan adanya sinergi antara keduanya, begitu juga bidang keilmuan tidak harus membedakan antara ilmu duniawi dan ilmu ukhrawi. Konsep dikotomi ilmu tidak diperkenankan oleh ulama salaf serta para ilmuwan terdahulu. Mayoritas ulama mempunyai keahlian dan keilmuan lebih dari satu macam yang membuktikan bahwa ulama salaf atau tradisional tidak mengenal perbedaan atau dikotomi ilmu. Seperti yang banyak di fahami oleh mayoritas orang sekarang bahwa ilmu agama meliputi bebrapa bidang ilmu seperti: (ilmu-keIslamanTafsir, Teologi, Fiqih, Hadits, dan lain sebagainya) serta disiplin ilmu bersifat umum (sains dan teknologi).

Belajar dasar keilmuan bidang agama itu fardu 'ain hukumnya, yaitu wajib bagi setiap orang yang beragama Islam untuk mempelajarinya. Sementara belajar ilmu yang bersifat umum yaitu fardu kifayah, Artinya apabila sudah tercukupi kebutuhannya maka gugur kewajiban bagi seorang muslim untuk mempelajarinya. Bidang keilmuan agama Islam sangatlah luas pembahasannya terkait dengan ilmu yang bisa dilihat oleh pancaindra maupun hal yang tidak bisa dilihat kasat mata atau bersifat Abstrak.

Secara konsep normatif menurut Abdul Rahman, Islam tidak mengenal istilah dikotomi ilmu. Di dalam Al-Quran dan Hadits kita tidak akan menemukan dalil yang menjadi dasar adanya dikotomi ilmu, sebaliknya Agama Islam menganjurkan untuk mencari ilmu dan mempelajari semua cabang ilmu. Ramayulis menjelaskan, dalam pendidikan Islam tidak mengenal batasan antara agama dan sains. keduanya adalah tuntutan akidah Islam. Oleh sebab itu dalam dunia pendidikan tidak dibenarkan adanya dikotomi pendidikan sains dengan pendidikan agama. siswa harus memahami Islam keseluruhan way of life, minimal guru dapat melakukan perubahan perspektif pola pikir terkait konsep ilmu secara langsung dikaitkan dengan dasar keagamaan.

Dampak negatif dari adanya dikotomi ilmu pengetahuan umum general science dengan ilmu pengetahuan agama religious sciences, umat Islam lebih khusus lagi lembaga berbasis keislaman menjalankan "re-integrasi ilmu". Azra menerangkan tawbidic paradigm of sciences pada tingkatan konsep, disharmonisasi pada tingkat praktiknya sering terjadi pada masyarakat, yang disebabkan oleh adanya dikotomi kedua ilmu ilmu tersebut, dikotomi juga menjangkau wilayah epistemologis, yaitu antara akal dan intuisi atau wahyu, antara "ilmu umum" dengan "ilmu agama". Oleh karena itu, untuk Memberikan Solusi para ulama dan ilmuwan serta cendikiawan menawarkan konsep klasifikasi dengan hirarki. 
Azyumardi Azra dalam kutipannya, segala jenis cabang ilmu pengetahuan di dalam persepektif Islam merupakan wujud dari satu kesatuan, dalam Islam tidak ada pemisah yang bersifat esensial terkait ilmu umum dengan ilmu agama. banyak intelektual muslim seperti $\mathrm{Al}$ Farabi, Al-Kindi, Al-Ghazali, Ibnu sina, Nashir AlDin Al-Thusi sampai, Mulla Shadra, dalam berbagai perspektif multi disiplin keilmuannya yang dikembangkan dalam sejarah kemajuan Islam secara hieraraki, pada akhirnya bermuara pada pengetahuan "Hakikat Yang Maha Tunggal" tentang subtansi dari segenap intelektualitas keilmuannya.

alasan dan bukti para ilmuwan muslim berupaya mengkorelasikan ilmu yang dikembangkan oleh peradaban non-Muslim kedalam hierarki ilmu pengetahuan Islam. Imam Asy-Syafi'I sendiri merumuskan landasan dasar pola berpikir tersebut, dijelaskan oleh Ar-Razi terkait perbandingan dengan Aristoteles dengan sistem filsafat metodologi mantiqnya (logika), Asy-Syafi'i dalam master piece-nya, ar-Risalah merumuskan konsep berpikir dalam beragama yang tertuang dengan metodologi ushul fiqhnya. hal ini menandakan bahwa pembentuan kaidah hukum Islam (ushul figh) bersinergi dan terkoneksi dengan pemikiran bidang filsafat.

Al-Kindi seorang filosof Muslim pertama yang berusaha mencarikan solusi atas adanya permasalahan klasifikasi keilmuan. pertama yaitu al-ulum al-qolbiyah, adalah ilmu yang diberikan Tuhan melalui wahyu, dengan perantara pengguanaan nalar dan akal. Klasifikasi kedua yaitu al-ulum al-aqliyyah, adalah ilmu intelektualitas, yang diperoleh melalui pengalaman pengujian empiris serta penggunaan akal. Dalam jenis-jenis Ilmu karyanya Fi Aqsam Al-Ulum . Buku tentang Hierarki ilmu karya Al-Farabi dalam Kitab Al-Ulum menjelaskan lebih luas figur yang mampu mengintegrasikan ilmu sampai didunia Barat antara lain Ibnu Rusydi, Al-Ghazali, Ibnu Sina, yang keilmuannya dijadikan rujukan.

Kompleksitas berkembangnya ilmu pada budaya perdaban Islam, ilmu agama merupakan sebagian ilmu Islam secara keseluruhan. Pada prakteknya kemajuan peradaban umat muslim selaras dengan kemajuan dibidang keilmuan. Apabila beberapa bidang ilmu dimakruhkan, atau diharamkan, terciptalah dikotomi yang berujung ketidak selarasan, penamaan nilai keilmuan yang berdasarkan Al-Quran dan Al-hadits masuk dalam kategori islami tidak serta merta dibenarkan, karena menimbulkan bidang ilmu lainnya seperti sejarah, psikologi, terkesan menjadikan tidak islami atau religius, sementara didalam Al-Qur`an tidak terdapat ayat yang kontradiktif antara cabang ilmu dengan subjek ilmu pengetahuan secara umum.

Agama dan Ilmu merupakan satu rangkaian yang tidak bisa dipisahkan, melainkan saling melengkapi dan menyempurnakan. pakar ilmu fisika Robert enstein menjelaskan "Agama tanpa ilmu adalah buta".doktrin agama merupakan muara dari segala jenis keilmuan. Knowledge bersandar ke philosophy yang tidak lain adalah induk dari segala pengetahuan yang bermuara kepada doktrinasi agama. Oleh karenanya ilmu merupakan cabang dari agama yang sifatnya bukan hanya duniawi saja, melainkan juga berorientasi pada ukhrowi. oleh karenanya pergeseran pemaknaan yang kurang begitu benar haruslah 
diluruskan dengan baik dan benar, yaitu ilmu adalah bagian dari proses akal indrawi manusia yang tujuannya untuk lebih mendekatkan diri kepada Allah SWT dengan mengetahui segala perintahnya dan menjauhi apa yang dilarang.

Persoalan di Indonesia tentang dikotomi ilmu dalam Islam adalah Permasalahan pemisah antara agama dan ilmu. Naim Mochtar menjelaskan penyebab utama adanya kesenjangan bidang pendidikan di Indonesia adalah dikotomi pendidikan yang tidak lain adalah warisan dari penjajahan Belanda.Dikotomi tumbuh pertama kali pada abad pertengahan sejarah peradaban Islam,dan masih banyak ditemui para pendidik maupun praktisi pendidikan di belahan dunia muslim yang salah satunya Indonesia,pada tataran wilayah konsep maupun kelembagaan yang bersifat formal. Mengkaji tentang dikotomi ilmu sangatlah menarik karena terkait langsung dengan masalah kelembagaan yang berimbas pada terjadinya sudut pandang antara pendidikan agama dengan pendidikan umum pada kelembagaan yang merupakan warisan kolonial Belanda.

Adanya tekanan politik kekuasaan dari pemerintah kolonial belanda, maka sekolah agama berbasis Islam memisahkan diri dan mencari komunitas yang sama dalam prinsip,Sehingga mulailah awal sejarah pendidikan terkotak-kotakan (dikotomi). Azyumardi Azra menerangkan dalam sejarah pendidikan Islam terdapat "kecelakaan sejarah atau "historical accident, yang berawal ketika ilmu umum atau keduniaan yang berprinsip pada penelitian empiris, logika, rasio, Pasca kemerdekaan, pemerintahan kolonial Belanda mewariskan dualisme agar tetap Eksis serta tertanam dalam dunia pendidikan di Indonesia.
Sebagian pejabat yang menaungi bidang pendidikan kurang antusias serta tidak menghargai sekolah berbasis Islam,sehingga sebagian para pengelola sekolah islam tersebut berpegang pada sikap semula, berdiri sendiri di zona pilihan yang berbeda dengan sekolah umum. peran Departemen Agama dalam menangani sekolah keagamaan sangatlah diperlukan. Dikarenakan dikotomi lembaga pendidikan sekolah mulai berjalan dengan arah nahkoda kepemimpinannya masing-masing. Dengan fungsi dan tugasnya dibidang pendidikan, Departemen agama memberikan konsep dasar konvergensi yaitu memasukkan pelajaran umum dalam kurikulum sekolah agama yang berada dalam naungan Departemen Agama.

Agama dan ilmu merupakan hasil pemikiran manusia terhadap hakikat kebenaran Allah, yang secara qauniyah maupun aqliyah terus berkembang secara kontinyu. Inti pemahaman tersebut yaitu kepatuhan manusia dan keimanan kepada Allah yang tercermin oleh sikap dan prilaku, Dikeluarkannya surat keputusan tiga menteri yaitu, Mendagri, Menteri Agama, Menteri Pendidikan, SKB tiga Menteri tentang peningkatan mutu pendidikan madrasah menjadi awal usaha bersama untuk menghapus dikotomi pendidikan di Indonesia, walaupun pada realitanya secara kelembagaan terus berjalan.

\section{Faktor Penyebab Terjadinya Dikotomi Pendidikan}

Dalam dunia pendidikan Islam dikotomi terjadi dikarenakan terdapat beberapa faktor. Pertama, faktor bidang pengembangan ilmu yang terus berkembang begitu cepat sampai 
menghasilkan cabang disiplin ilmu baru, sehingga dapat menjadi jarak antara cabang disiplin ilmu dengan ilmu induknya, ilmu umum dengan ilmu agama semakin jauh. Epistemology memunculkan struktur ilmu pengetahuan hingga ke anak cabang ilmu, contohnya filsafat sebagai mother off all sciences (induk segala ilmu pengetahuan) terdapat pengklasifikasian struktur ilmu, seperti ilmu pendidikan, menjadi cabang ilmu yang semakin detail dan rinci, psikologi pendidikan, teknolgi pendidikan, sosiologi pendidikan, dan seterusnya.

Inilah yang menyebabkan munculnya spesialisasi keilmuan, dari cabang ilmu pendidikan terpecah lagi menjadi anak cabang disiplin ilmu tersebut, menjadi strategi belajar mengajar, pengembangan pendidikan, perencanaan kurikulum, perencanaan serta pelaksanaan pendidikan, dan lain sebagainya yang berkaitan dengan bidang pendidikan dan pembelajaran. hal ini yang menyebabkan jarak semakin jauh antara anak cabang ilmu dengan ilmu filsafat sebagai mother off all sciences, yang menjadikan pelaksananya semakin ahli atau profesional dalam penguasaan bidang ilmu pendidikan.

Kedua, faktor sejarah budaya umat Islam yang mengalami masa kemunduran atau stagnan pada Abad Pertengahan sekitar tahun 1250-1800 Masehi, yang tidak lain dikarenakan sebuah kesalahan sejarah yang sampai saat ini pengaruhnya bisa dirasakan, waktu itu yang mendominasi ahli agama atau ulama fiqh dalam pendidikan Islam, sampai terkesan bahwa mempelajari ilmu agama tergolong sebuah keharusan atau wajib bagi semua ummat islam, sehingga terjadi kristalisasi keilmuan, sedangkan mempelajari ilmu umum merupakan kewajiban kolektif atau fardlu kifayah, Akibatnya Negara Indonesia yang mayoritas berpenduduk muslim kalah bersaing dalam bidang iptek atau ilmu pengetahuan dan teknolgi bila dibandingkan dengan Negara lain.

Ketiga, faktor permasalahan internal bidang hukum, politik, sosial, ekonomi, dan budaya yang dihadapi penduduk masyarakat Indonesia mayoritas beragama Islam. tidak mampu melakukan upaya pembenahan dan pembaruan di kelembagaan bidang pendidikan Islam yang akibatnya, terjadi dikotomi ilmu agama dan ilmu umum. pola pemikiran dikotomisasi masih terdapat dalam kelembagaan pendidikan Islam yaitu antara urusan ukhrawi dengan duniawi, ilmu dan iman, Akal dan Wahyu, Ilmu agama dengan Umum sehingga masyarakat mempunyai paradigma berfikir yang terkotakkan seperti itu seperti doktrinasi sebuah jarak pemisah.

Akar permasalahan dikotomi pada berbagai disiplin ilmu di Indonesia, secara gamblang dijelaskan yaitu pertama kaitannya objektifitas bidang pendidikan Islam, dengan terjadinya krisis konseptual secara epistemologisnya. Membatasi ilmu pada sistem bidang pendidikan Islam yang terdapat aturan Sistem Pendidikan Nasional. pada prinsipnya dikotomi keilmuan bidang pendidikan pada kelembagaan disebabkan ketidak fahaman pemaknaan antara pendidikan Islam sebagai disiplin ilmu dengan Pendidikan Islam sebagi kelembagaan formal bidang Pendidikan. ketidakmampuan membedakan pemaknaan arti pendidikan Islam dengan pendidikan agama Islam yang dimaksud adalah pembagian ilmu.

Terdapat Istilah ilmu profane, adalah ilmu 
keduniawian yang berkaitan erat dengan ilmu agama yang bersifat transenden (sacral).karena dalam agama islam ada beberapa disiplin ilmu yang memang berada pada bidang ketauhidan secara aturan syariat yang tidak boleh dibatasi dalam proses teori maupun praktiknya, dan tidak bisa dibatasi oleh adanya kelembagaan yang kurikulum mengikuti Standar system pendidikan Nasional, Sehingga berimplikasi ketidaksesuaian antara keilmuan berlandaskan keislaman dengan ilmu umum, yang menyebabkan pengkotakan adanya gap pada bidang pendidikan dan selanjutnya menimbulkan krisis kelembagaan.

Dualisme pendidikan di Indonesia merupakan dikotomisasi antara lembaga pendidikan sehingga menjadikan adanya Krisis kelembagaan, dan persaingan antar lembaga pendidikan misalnya amanya adrasah dan pesantren sebagai bentuk identitas pendidikan agama, di tingkatan perguruan tinggi terdapat perguruan tinggi umum dan Universitas Islam Negeri. Yang menyebabkan, unsur ketersediaan anggaran dana yang berbeda pula antara lembaga yang di bawah naungan kementerian pendidikan dengan kementerian Agama, yang secara tidak langsung akan mempengaruhi adanya fasilitas sarana dan prasarana, seiring berjalannya waktu UIN yang dalam naungan Kementerian Agama dapat mengembangkan sayapnya dengan membuka beberapa fakultas yang dinilai produktif dan bernilai tawar tinggi dengan kebutuhan masyarakat seperti halnya membuka Fakultas Ekonomi Syariah, Tadris, dan jurusan ilmu umum lainnya yang dapat menjadikan sedikit banyak dalam mengatasi kesenjangan dan dikotomi dalam kelembagaan pendidikan.
Prasyarat menghilangkan adanya dualisme pada sistem pendidikan,dan diteruskan dengan menghilangkan dualisme pada kehidupan seharihari, untuk mengisi kembali Ruh dan marwah berbagai disipilin ilmu dengan kerangka pemikiran yang sesuai tanpa membedakan identitas kelembagaan yang ada antara kementerian pendidikan dengan kementerian Agama dalam artian terdapat nilai yang sama dalam operasional maupun konsep implementasinya, sehingga menjadikan masyarakat lebih mudah dalam memilih dan memilah adanya dikotomi pada kelembagaan. Dan penguasaan materi baik dari segi agama maupun ilmu umum, sehingga tidak terjadi istilah insinyur awam dalam ilmu keagamaan.

\section{Memahami sejarah terbentuknya dikotomi pendidikan di Indonesia}

Otoriter kolonial belanda membuat para pribumi menjadi bersatu untuk melawan imperialisme penjajahan. ulama, santri, pedagang, dan masyarakat yang lainnya membuat sebuah gerakan perlawanan untuk menentang kesewenang-wenangan belanda, sehingga pada tahun 1820-1880 pertumbuhan pondok pesantren yang menentang imperialisme Belanda bermunculan, Hal ini menimbulkan kecurigaan Pemerintah Belanda terhadap Islam. Sampai akhirnya Belanda memperkenalkan sekolah pendidikan dasar kepada kaum pribumi yang awalnya hanya terbatas untuk keturunan kolonial belanda. Pada tahun 1870 belanda mulai membuka sekolahan umum bagi penduduk pribumi putera yaitu SR (sekolah rkyat). Tujuan utamannya adalah factor politik praktis untuk kepentingan Belanda 
yaitu meningkatkan produktivitas jajahannya di tanah jawa.

Zakiah menjelaskan dalam bukunya bahwa pemerintahan Belanda, tidak memberikan pendidikan agama di sekolah negeri dengan dalih pemerintah harus nasional dan netral dengan tidak ikut campur dalam urusan pendidikan keagamaan, oleh karenanya sudah tanggung jawab pribadi dan keluarga, beberapa kali usulan dari perwakilan rakyat asli pribumi di Volksraad untuk menjadwalkan pelajaran agama Islam di universitas tinggi umum selalu gagal dan ditolak, hanya di sekolah swasta atau partikulir diperbolehkan berdasarkan keagamaan, kontrol dari pemerintah belanda yang sangat ketat dan otoriter, dijadikan sebagai penghambat untuk menghalangi pelaksanaan pendidikan Agama Islam.

Bagi pribumi oleh Pemerintah kolonial Belanda menyelenggarakan pendidikan sendiri dan mereka hanya melakukan pengawasan seiring berjalannya kegiatan belajar mengajar, Kebijakan yang dibuat hanya mementingkan golongan kaum elit saja, dan mengesampingkan aspiratif kepentingan mayorits umat muslim pada waktu itu yang menjadi awal kali terciptanya dualisme terhadap dunia pendidikan dan berbagai permasalahan yang menyangkut kepentingan umat muslim di Indonesia. Dalam konteks sejarah, dikotomi pendidikan di Indonesia, berawal adanya sistem dalam dunia pendidikan modern.

\section{KESIMPULAN}

Dikotomi pada dunia pendidikan di Indonesia di sebabkan oleh beberapa factor, Pertama yaitu dikotomi adalah sebuah warisan sejarah oleh kolonial pemerintah belanda, kebebasan beragama diberikan oleh penjajah, akan tapi setengah hati dalam pelaksanaan di dunia pendidikan. terbukti dengan memberikan kebebasan untuk memilih dan melanjutkan pendidikan hanya dibatasi oleh kaum bangsawan saja. Kedua, dikotomi juga terjadi pada kelembagaan pendidikan, yang merupakan sebuah pembatas bagi pendidikan bidang agama yang dalam naungan departemen Agama sedangkan pendidikan umum bernaung pada departemen pendidikan yang menjadikan pengkotak-kotakan serta lebih memprioritaskan pendidikan Umum kaitan dengan anggaran pendanaan pada waktu itu. Ketiga, factor politik yang sangat berpengaruh terutama pada kebijakan strategis yang dikuasai oleh elit politik yang cenderung memihak kepada pemerintah belanda.

Oleh karena itu solusi untuk menghilangkan serta meminimalisir adanya dikotomi pendidikan di Indonesia adalah: paradigma dan Pemahaman masyarakat adanya kesan pemisahan antara ilmu umum dengan ilmu agama dapat dihilangkan dengan cara peran serta aktif masyarakat, karena dikotomi merupakan produk dari kolonial belanda yang bertujuan untuk pemisahan, dan sebuah wujud kesalahan sejarah/bistorical accident' dengan memarginalkan penyebaran ideologi keislaman.

Perlu adanya sinergi antara masyarakat, pemerintah, serta praktisi pendidikan untuk menghilangkan kesan adanya dikotomi dan dualism pendidikan, yang masing-masing sesuai tupoksi untuk menjadikan pendidikan central dari ilmu baik ilmu Agama maupun ilmu Umum, dan juga lembaga pendidikan dalam naungan departemen Agama yang sekarang berubah 
menjadi kementerian Agama dengan kementerian pendidikan nasional.kesadaran masyarakat guna sebagai stekholder pendidikan haruslah cerdas dalam memasukkan putra putrinya di lembaga pendidikan, jangan sampai terkotak-kotakan dengan adanya dikotomi dan dualism tersebut.

\section{DAFTAR PUSTAKA}

Hamid, Abdullah dkk, (2010). Pemikiran Modern Dalam Islam. Bandung, Pustaka Setia.

Nata, Abudin. (2008). Manajemen Pendidikan, Mengatasi kelemahan pendidikan Islam di Indonesia. Jakarta : Kencana Prebada Media Group.

Ma'arif, Ahmad Syafi'i. (1997). "Pengembangan Pendidikan Tinggi Post Graduate Studi Islam Melalui Paradigma Baru yang Lebih Efektif". Makalah Seminar Tidak Diterbitkan.

Tafsir, Ahmad. (2007). Ilmu Pendidikan dalam Perspektif Islam. Bandung : Remaja Rosdakarya.

Tilar, H.A.R. (1998). Beberapa Agenda Reformasi Pendidikan Nasional Dalam Perspektif Abad 21. Magelang: Tera Indonesia.

Rahim, Husni. (2000). Arah Baru Pendidikan Islam di Indonesia. Jakarta: Logos Wacana Ilmu.

Al-Faruqi, Isma'il Raji. (1982). Islamization of Knowledge : General Principles and Workpla. Hemdon : HIT.

Muliawan, Jasa Ungguh. (2005). Pendidikan Islam Integratif: Upaya Mengintegrasikan Kembali dikotomi Ilmu dan Pendidikan Islam. Yogyakarta : Pustaka Pelajar.

Echols, John M. dan Shadily, Hassan. (1992) Kamus Inggris-Indonesia. Jakarta : PT. Gramedia Utama.

Jalaludin; Said, Usman. (1999). Filsafat Pendidikan Islam, cet. III. Jakarta: Raja Grafindo Persada.

Mastuhu. (2004). Menata Ulang Pemikiran Sistem Pendidikan Nasional dalam Abad 21. Yogyakarta: Safiria Insani Press.

M. Shofan, M. (2004). Pendidikan Berparadigma
Profetik. Yogyakarta: Ircisod-UMG Press.

Maksum, Madrasah Sejarah dan Perkembangannya, (Jakarta : Logos Wacana Ilmu, 1999)

Marwan Saridjo, Marwan. (1996). Bunga Rampai Pendidikan Agama Islam, Jakarta: Amissco.

Isa, Kamal Muhammad. (1994). Manajemen Pendidikan Islam (terj). Khashaish Madrasatin Nubuwawah. Jakarta: Fikahati Aneska.

Mahmud Arif, Mahmud. (2008). Pendidikan Islam Transformatif. Yogyakarta: LKIS.

Djamas, Nurhayati. (2009). Dinamika Pendidikan Islam di Indonesia Pasca Kemerdekaan. Jakarta: PT Raja Grafindo Persada.

Nasir, Ridlwan, (2005). Mencari Tipologi Format Pendidikan IdialPondok. Pesantren di Tengak Arus Perubahan. Yogyakarta: PustakaPelajar.

Usa, Muslih (ed). (1991). Pendidikan Islam Sebagai Upaya Pembebasan Manusia, dalam Buku : Pendidikean Islam di Indonesia antara Cita dan Fakta. Yogyakarta : Tiara Wacana.

Shihab, Quraish. (2007). Wawasan Al-Quran: Tafsir Maudhu'I atas Pelbagai Persoalan Ummat. Bandung: Mizan. 
